\title{
Effect of Attractions, Social Media, Quality of Service and Facilities on Revisit Interest with Customer Satisfaction as Intervening Variables to Geopark Kaldera Toba in Sianjur Mulamula Village
}

\author{
Agung Solikhin Harahap ${ }^{1}$, Endang Sulistya Rini ${ }^{2}$, Fadli ${ }^{2}$ \\ ${ }^{1}$ Postgraduate Students, Department of Management, Faculty of Economics and Business at Universitas \\ Sumatera Utara, Indonesia \\ ${ }^{2}$ Postgraduate Lecturer, Department of Management, Faculty of Economics and Business at Universitas \\ Sumatera Utara, Indonesia
}

Corresponding Author: Agung Solikhin Harahap

\begin{abstract}
The purpose of this study was to determine and analyze effect of attractions, social media, quality of service and facilities on revisit interest with customer satisfaction as intervening variables to Geopark Kaldera Toba in Sianjur Mulamula Village. This type of research is descriptive quantitative with a research sample of 100 respondents who visited Sianjur Mulamula Village. Data collection techniques by distributing questionnaires to respondents. Hypothesis testing in this study was carried out using path analysis. The results of this study indicate that attractions has effect on customer satisfaction and revisit interest, quality of service has effect on customer satisfaction, and customer satisfaction has effect on revisit interest. While social media and facilities have no effect on customer satisfaction, and social media, quality of service, and facilities have no effect on revisit interest. Customer satisfaction is not able to mediate between social media with revisit interest, and customer satisfaction is able to mediate between attractions, quality of service, and facilities with interest in revisiting.
\end{abstract}

Keywords: Attractions, Social Media, Quality of Service, Facilities, Revisit Interest, Customer Satisfaction

\section{INTRODUCTION}

Indonesia is a country that has a lot of tourism potential and makes it an alternative choice for world tourism destinations. The Indonesian tourism industry is one part of the industrial sectors whose prospects are very promising and have the potential and opportunities to continue to grow. The natural conditions of a place such as geographical location and conditions, fertile soil layers and panoramas (due to geological ecology), as well as the presence of flora and fauna that enrich the contents of land and sea are the intended potential to develop.

Not only diverse natural attractions, cultural tourism, pilgrimages, and history in Indonesia are no less interesting. This is because Indonesia has hundreds of cultural tribes spread from Sabang to Merauke. It can be said that Indonesia has a complete package that can be the main selling point of the tourism sector. The results of the LPM UI 2018 research show that the tourism sector in general has an important role in the Indonesian economy which is illustrated by the multiplier effect in Indonesia. This multiplier effect causes all tourist spending, investment spending, government spending to have an economic impact in the form of increased output, added value, income, and the creation of workers in Indonesia.

Based on the growth of tourist arrivals, especially foreign tourists to Indonesia, it grew three times the regional and global 
Agung Solikhin Harahap et.al. Effect of attractions, social media, quality of service and facilities on revisit interest with customer satisfaction as intervening variables to Geopark Kaldera Toba in Sianjur Mulamula Village.

growth rate. Indonesia's tourism sector has a significant contribution to generating a foreign exchange surplus as the second largest foreign exchange earner of 17.6 billion.

The country's foreign exchange earnings from the tourism sector also experienced a significant decline. The projection of foreign exchange earnings from tourism in 2020 is between US\$4-7 billion. Prior to the pandemic, tourism foreign exchange earnings in 2020 were targeted at US\$19-21 billion. When compared to 2019 , the decline was quite significant because tourism foreign exchange earnings in the previous year almost reached US\$20 billion (Kompas.com, 2020). Several policies have been pursued by the government, particularly the Ministry of Tourism and Creative Economy, to restore the tourism sector while still focusing on restoring health. It is hoped that after the pandemic period ends, Indonesian tourism will soon rise as one of the main sectors in driving the national economy.

Many tourist destinations in Indonesia have great potential to develop and are widely known by tourists, both local and foreign tourists. The Indonesian government has officially established ten new tourist destinations or also called 10 New Bali destinations which are prioritized in order to be able to bring in tourists quickly. One of the ten tourist destinations is Lake Toba in North Sumatra which is a super priority. Followed by Tanjung Kelayang in Belitung, Tanjung Lesung in Banten, the Thousand Islands in DKI Jakarta, Borobudur Temple in Central Java, Mount Bromo in East Java, and Mandalika in West Nusa Tenggara. Moreover, the existence of Lake Toba itself is also coupled with the inauguration of Lake Toba as a Global Geopark by UNESCO which is expected to have a positive impact on Indonesian tourism and especially for the people around Lake Toba.

Geopark is an area that has prominent geological elements, including archaeological value, biodiversity and ecology and culture in it (UNESCO, 2004). The purpose of Geopark development is to explore, develop, maintain and preserve the relationship/relationship between geological heritage and all aspects of human life such as natural heritage and cultural heritage in an area. Toba Caldera Geopark is a main driving tool to improve and develop a Geotourism-based economy in the Lake Toba area, this concept can be used as a tourist attraction as well as for community empowerment, because this concept is a scientific-based concept, which has the function of education, geo-ecological conservation, and sustainable community economic development.

The beauty of extraordinary natural scenery, fascinating arts and culture, as well as very friendly people, attract tourists from all over the world to come to enjoy the panorama and views of Lake Toba. The government itself has set a target for foreign tourist visits to Lake Toba to be 1 million people in 2019. The Toba Caldera Geopark area has beautiful natural and cultural panoramas. Toba Caldera itself was formed from the massive eruption of Mount Toba, about 74,000 years ago. The eruption of the Ancient Toba Volcano left a deep indentation at the base of the caldera which then filled with water, and is known as Lake Toba. Its depth reaches about 550 meters and an area of 1,130 square kilometers. After the eruption and the formation of a caldera or lake, these geological events also created another formation, namely Samosir Island which occurred due to the lifting of most of the lakes to the surface.

To understand the Toba Caldera Geopark, we must start the journey from Pusuk Buhit which is located on Samosir Island close to a village known as Sianjur Mulamula Village. Sianjur Mulamula Village is included in the Sianjur Mulamula District which has many geosites compared to other villages in the District. The inclusion of Sianjur Mulamula Village into the Toba Caldera Geopark area, makes the village potential for the development of the 
Agung Solikhin Harahap et.al. Effect of attractions, social media, quality of service and facilities on revisit interest with customer satisfaction as intervening variables to Geopark Kaldera Toba in Sianjur Mulamula Village.

tourism sector. In addition, Sianjur Mulamula Village itself has a lot of geological, biological and cultural diversity which is expected to be able to empower the community through the tourism sector. In the Sianjur Mulamula area, it is also believed to be the origin of the Batak people. From here, the Batak people go to all corners of Indonesia and the world. Around the village of Sianjur Mulamula there is also a magnificent building, the Toba Caldera Geopark Information Center. The Toba Caldera Geopark Information Center is under the supervision of the Toba Caldera Geopark Management Agency and functions to provide information and education for tourists about Toba Caldera.

The development and success of the tourism industry in Indonesia cannot be separated from the interest in revisiting tourists, both local and foreign tourists. Interest in visiting in Marketing for Hospitality and Tourism is assumed to be the same as buying interest (Kotler, 2014). Interest to revisit a place is based on consumer plans to make purchases of certain products or services.

Consumer interest in returning to a place is certainly based on certain reasons, where the visit can provide value benefits that will have an impact on customer satisfaction. The selection of tourist destinations is determined by tourists according to the tastes and needs of tourists. Aziz et al. (2012) stated that the intention of visitors to revisit a particular destination can be influenced by the performance of the attraction or tourist destination itself, such as promotional efforts and news about tourist attractions. There are various components in tourism products that can be a consideration for tourists to visit tourist destinations.

Ginting (2012) states that satisfaction is a person's perceived perception of an object or activity. Tourist satisfaction is the perception felt by tourists in carrying out their tours and after doing their tours. Satisfaction contains a general perception that develops in a consumer about a product or service after its purchase. In this day and age, more and more regions or countries rely on the tourism industry for their economy, thus making tourism business competition even tighter. A tourist destination with great potential often has difficulty in maintaining its position as a tourist destination of choice. The results of other related studies are the results of Nurlestari's research (2016), but in this study it is said that tourist satisfaction does not have a significant influence on the intention of repeat visits at Taman Safari Indonesia Cisarua Bogor. Therefore, tourism business actors or managers must be aware of the importance of increasing the understanding of tourist satisfaction and loyalty factors as valuable information for the sustainability of tourism businesses.

At this time where the era of the industrial revolution 4.0 has developed, the effectiveness of using digital as a medium for disseminating information lies in its unlimited nature and is able to reach all elements in various parts of the world. Technological developments also allow the delivery of interesting content in the form of text, images, audio, and video that can provide clear information about the products and services offered. Social media is also widely used by the tourism industry. The existence of digital media is believed to be a new breakthrough for the marketing world in disseminating information and promoting something in an effective way and is expected to be able to reach the desired target market which of course has greater potential than conventional methods. Trusov et al. (2009) stated that social media has become a very powerful "Word of Mouth" tool because social media gives users the freedom to share their experiences and opinions with the wider community. This can have a positive influence on users if there are users who are satisfied and can also have a bad influence if users are disappointed.

The potential of social media as a means of interactive promotion for Indonesian tourism is interesting and much 
Agung Solikhin Harahap et.al. Effect of attractions, social media, quality of service and facilities on revisit interest with customer satisfaction as intervening variables to Geopark Kaldera Toba in Sianjur Mulamula Village.

needed in an effort to improve the tourism industry. Instagram, Facebook, Tripadvisor, Youtube, are various social media that are widely used today. Content uploaded by tourists to tourist destinations on social media also contributes significantly not only to the tourism service business, but also provides benefits to tourists who will travel, including information about service quality, experience, to attractive price variations. In research conducted by Arhisondha (2012), it was shown that social media, both Facebook, YouTube and Instagram, had an influence on the interest of returning tourists. The emergence of internet-based social media allows one person to communicate with hundreds or even thousands of other people, so this can be used to introduce and promote tourism destinations.

The purpose of this study was to determine and analyze effect of attractions, social media, quality of service and facilities on revisit interest with customer satisfaction as intervening variables to Geopark Kaldera Toba in Sianjur Mulamula Village.

\section{RESEARCH METHODS}

This type of research is descriptive quantitative. Quantitative descriptive research includes collecting data to test hypotheses or answer questions about the latest status of research subjects (Pandiangan et al., 2018).

The population in this study are tourists who have been to Geopark Kaldera Toba in Sianjur Mulamula Village. Research sample of 100 respondents who visited Sianjur Mulamula Village.

Data collection techniques by distributing questionnaires to respondents.

Hypothesis testing in this study was carried out using path analysis.

\section{RESULT}

\section{Description of Research Object}

Based on data from the Central Statistics Agency for Samosir district, 99.23\% of the population of this sub-district embraced Christianity, of which $60.57 \%$ were Protestant and $38.66 \%$ Catholic. Then some of them embraced Islam, namely $0.64 \%$ and Parmalim $0.13 \%$. For places of worship, there are 31 Protestant churches and 15 Catholic churches.

Sianjur Mulamula is one of 12 villages located in Sianjur Mulamula District, Samosir Regency, North Sumatra Province. Sianjurmulamula sub-district has a population of 10.003 people while the population in Sianjur Mulamula Village itself is 587 people with an area of 16.54 $\mathrm{km}^{2}$.

Sianjur Mulamula Village is only known as a large sub-district. However, few people know that Sianjur Mulamula is also a very large village and an extraordinary view. This village has a lot of potential to be used as a sustainable tourism area. There are several tourist attractions that can be visited in Sianjur Mulamula Village including: (1)Hadabuan Nai Sogop Waterfall, (2)Si Raja Batak's House, (3)Sianjur Mulamula Trees, (4)Aek Bintatar, (5)Village views and Rice Fields.

Access to the location of Sianjur Mulamla Village can be reached by land, water, and air. The achievement by land through the city of Medan can be reached from Kuala Namu Airport via the MedanTebing Toll Road then past Pematangsiantar City and takes 4 hours to reach Tigaras port to take a 1 hour ferry so that you can arrive at Simanindo port. Arriving at the port of Simanindo, the road trip is then continued by taking 1 hour to arrive at Pangururan City with 1 hour after that you can also continue the journey to Simpang Limbong with a travel time of half an hour from Pangururan City. Arriving at Simpang Limbong, you have to use transportation from the surrounding community to get to Sianjur Mulamula with a distance of about 15 minutes.

\section{Characteristics of Respondents}

Respondents in this study were 100 people who had visited the Sianjur Mulamula tourist attraction. 
Agung Solikhin Harahap et.al. Effect of attractions, social media, quality of service and facilities on revisit interest with customer satisfaction as intervening variables to Geopark Kaldera Toba in Sianjur Mulamula Village.

Based on the data, it can be seen that the majority of respondents in this study were male respondents as many as 56 people and female respondents as many as 44 people. It can be concluded that the majority of respondents in this study were male respondents.

From the results of this study, it can be seen that the characteristics of respondents based on age less than 20 years were 15 people. For respondents aged 21-30 years as many as 45 people, aged $31-40$ years as many as 25 people and those aged over 40 years as many as 15 people. From these results it can be seen that the majority of respondents in this study were respondents aged 21-30 years.

Based on the data, it can be seen that in terms of work, respondents who visited Sianjurmulamula were 15 students, 17 civil servants, 28 private employees and 40 entrepreneurs. From these results indicate that the majority of respondents in this study are respondents who work as entrepreneurs.

Based on the data, it can be seen that the characteristics of the respondents based on the level of visits were 57 people for the first time visiting the Sianjurmulamula tourist attraction. While the respondents who have visited the tourist attraction Sianjurmulamula more than once were 43 people. It can be interpreted that the majority of respondents in this study are visitors who are visiting Sianjurmulamula for the first time.

\section{Hypothesis Testing}

To see the results of the substructural hypothesis for the first model, it can be done with a partial test as follows:

Table 1. Partial Test Sub Structure I

\begin{tabular}{|c|c|c|c|c|c|c|}
\hline \multicolumn{7}{|c|}{ Coefficients $^{\mathrm{a}}$} \\
\hline \multirow{2}{*}{\multicolumn{2}{|c|}{ Model }} & \multicolumn{2}{|c|}{ Unstandardized Coefficients } & \multirow{2}{*}{$\begin{array}{l}\text { Standardized Coefficients } \\
\text { Beta }\end{array}$} & \multirow[t]{2}{*}{$\mathbf{T}$} & \multirow[t]{2}{*}{ Sig. } \\
\hline & & B & Std. Error & & & \\
\hline \multirow[t]{5}{*}{1} & (Constant) & .161 & .468 & & .345 & .731 \\
\hline & Attractions & .647 & .063 & .615 & 10.345 & .000 \\
\hline & Social Media & -.108 & .072 & -.079 & -1.495 & .138 \\
\hline & Quality of Service & .353 & .059 & .352 & 5.973 & .000 \\
\hline & Facilities & .083 & .053 & .084 & 1.584 & .117 \\
\hline \multicolumn{7}{|c|}{$\begin{array}{l}\text { a. Dependent Variable: Customer Satisfaction } \\
\text { Source: Research Results (2021) }\end{array}$} \\
\hline
\end{tabular}

Table 2. Partial Test Sub Structure II

\begin{tabular}{|c|c|c|c|c|c|c|}
\hline \multicolumn{7}{|c|}{ Coefficients $^{\mathrm{a}}$} \\
\hline \multirow{2}{*}{\multicolumn{2}{|c|}{ Model }} & \multicolumn{2}{|c|}{ Unstandardized Coefficients } & \multirow{2}{*}{$\begin{array}{l}\text { Standardized Coefficients } \\
\text { Beta }\end{array}$} & \multirow[t]{2}{*}{$\mathbf{T}$} & \multirow[t]{2}{*}{ Sig. } \\
\hline & & $\mathbf{B}$ & Std. Error & & & \\
\hline \multirow[t]{6}{*}{1} & (Constant) & 4.678 & .859 & & 5.447 & .000 \\
\hline & Attractions & -.576 & .167 & -.547 & -3.440 & .001 \\
\hline & Social Media & .167 & .134 & .123 & 1.246 & .216 \\
\hline & Quality of Service & -.137 & .127 & -.137 & -1.080 & .283 \\
\hline & Facilities & -.071 & .098 & -.072 & -.729 & .468 \\
\hline & Customer Satisfaction & .488 & .188 & .488 & 2.593 & .011 \\
\hline
\end{tabular}

Table 3. Indirect and Direct Effects

\begin{tabular}{|l|l|l|}
\hline Variable Name & Indirect Effects & Direct Effects \\
\hline Attractions $\rightarrow$ Customer Satisfaction $\rightarrow$ Revisit Interest & 0.300 & -0.547 \\
\hline Social Media $\rightarrow$ Customer Satisfaction $\rightarrow$ Revisit Interest & -0.039 & 0.123 \\
\hline Quality of Service $\rightarrow$ Customer Satisfaction $\rightarrow$ Revisit Interest & 0.172 & -0.072 \\
\hline Facilities $\rightarrow$ Customer Satisfaction $\rightarrow$ Revisit Interest & 0.041 & -0.137 \\
\hline
\end{tabular}

Source: Research Results (2021)

The results of this study indicate that attractions has effect on customer satisfaction and revisit interest, quality of service has effect on customer satisfaction, and customer satisfaction has effect on revisit interest. While social media and facilities have no effect on customer satisfaction, and social media, quality of service, and facilities have no effect on revisit interest. Customer satisfaction is not able to mediate between social media with revisit interest, and customer satisfaction is 
Agung Solikhin Harahap et.al. Effect of attractions, social media, quality of service and facilities on revisit interest with customer satisfaction as intervening variables to Geopark Kaldera Toba in Sianjur Mulamula Village.

able to mediate between attractions, quality of service, and facilities with interest in revisiting.

\section{CONCLUSION AND SUGGESTION Conclusion}

The results of this study indicate that attractions has effect on customer satisfaction and revisit interest, quality of service has effect on customer satisfaction, and customer satisfaction has effect on revisit interest. While social media and facilities have no effect on customer satisfaction, and social media, quality of service, and facilities have no effect on revisit interest. Customer satisfaction is not able to mediate between social media with revisit interest, and customer satisfaction is able to mediate between attractions, quality of service, and facilities with interest in revisiting.

\section{Suggestion}

Suggestions in research are:

1. Researchers can suggest to further researches in order to expand the research variables, because in an effort to generate interest in revisiting tourists, there will be very many variables that influence it.

2. Researchers also suggest to tourism managers to be able to manage tourist attractions in Sianjur Mulamula village well, such as preserving local culture there. In addition, tourism managers are also expected to be cooperative with the rules that have been given by the government, such as maintaining and caring for the facilities that have been developed by the government.

3. Researchers can also give suggestions to local governments to further develop the Sianjur Mulamula tourist spot because this place is a historical place which is said to be the first village of the Batak people. For this reason, the government can build more adequate facilities and build cultural heritage that is almost damaged. In addition, it is very necessary for tourists to be able to learn about the history of Sianjur Mulamula by building such as the Sianjur Mulamula History Gallery.

4. Researchers can also provide advice for the Sianjur Mulamula village community to be able to preserve the environment, be friendly with etiquette according to eastern traditions, so that all tourists who come feel honored when visiting Sianjur Mulamula tourist attractions.

Acknowledgement: None

\section{Conflict of Interest: None}

\section{Source of Funding: None}

\section{REFERENCES}

1. Arhisondha, A. T. (2012). Pengaruh Media Sosial Terhadap Minat Berkunjung Ulang Wisatawan di Taman Geopark Kabupaten Merangin.

2. Aziz et al. (2012). Niat Pengunjung Mengunjungi Kembali ke Tujuan Tertentu.

3. Ginting, Nembah. (2012). Manajemen Pemasaran. Bandung: Yrama Widya.

4. Kompas.com. (2020). Kaldera Toba Ditetapkan Jadi UNESCO Global Geopark. Accessed from https://www.kompas.com/tren/read/2020/07 /08/141812465/kaldera-toba-ditetapkanjadi-unesco-global-geopark?page=all.

5. Kotler, P. (2014). Manajemen Pemasaran Perspektif Asia. Yogyakarta: Andy.

6. Kuncoro, Mudrajad. (2013). Metode Riset untuk Bisnis dan Ekonomi. Edisi 4. Jakarta: Erlangga.

7. Nurlestari, Ajeng Fitri. 2016. Pengaruh Daya Tarik Wisata Terhadap Niat Kunjungan Ulang Wisatawan dengan Kepuasan Wisatawan sebagai Variabel Intervening pada Taman Safari Indonesia Cisarua Bogor. Accessed from https://www.academia.edu/28971580/penga ruh_daya_tarik_wisata_terhadap_niat_kunju ngan_ulang_wisatawan_dengan_kepuasan_ wisatawan_sebagai_variabel_intervening_p ada_taman_safari_indonesia_cisarua_bogor.

8. Pandiangan, Saut Maruli Tua, Rujiman, Rahmanta, Tanjung, Indra I., Darus, Muhammad Dhio, \& Ismawan, Agus. (2018). An Analysis on the Factors which 
Agung Solikhin Harahap et.al. Effect of attractions, social media, quality of service and facilities on revisit interest with customer satisfaction as intervening variables to Geopark Kaldera Toba in Sianjur Mulamula Village.

Influence Offering the Elderly as Workers in Medan. IOSR Journal of Humanities and Social Science (IOSR-JHSS), 23(10), 76-79. DOI: $10.9790 / 0837-2310087679$. Accessed from http://www.iosrjournals.org/iosrjhss/papers/Vol.\%2023\%20Issue10/Version $-8 / \mathrm{K} 2310087679 . p d f$.

9. Trusov, Michael, Rudolph E Bucklin, \& Koen Pauwels. 2009. Effects of Word of Mouth Versus Traditional Marketing: Findings form an Internet Social Networking Site. Journal of Marketing.
10. UNESCO. (2004). UNESCO Global Geoparks (UGGp). Accessed from https://kniu.kemdikbud.go.id/?page_id=492.

How to cite this article: Harahap AS, Rini ES, Fadli. Effect of attractions, social media, quality of service and facilities on revisit interest with customer satisfaction as intervening variables to Geopark Kaldera Toba in Sianjur Mulamula Village. International Journal of Research and Review. 2021; 8(8): 342-348. DOI: https://doi. org/10.52403/ijrr.20210847 